\title{
PENGARUH ALOKASI ANGGARAN PENDIDIKAN DAN KESEHATAN TERHADAP INDEKS PEMBANGUNAN MANUSIA DAN DAMPAKNYA TERHADAP PERTUMBUHAN EKONOMI KOTA BITUNG
}

\author{
Susye Marlen Ketsy Lengkong, Debby Ch. Rotinsulu, Een N. Walewangko \\ Ekonomi Pembangunan - Fakultas Ekonomi dan Bisnis \\ Universitas Sam ratulangi
}

\begin{abstract}
ABSTRAK
Anggaran pendidikan maupun anggaran kesehatan merupakan salah satu komponen penting bagi berjalannya pembangunan manusia di sebuah daerah, dikarenakan adanya jaminan terhadap kualitas sumber daya manusia yang ada serta adanya kemampuan untuk menjaga sumber daya manusia yang dimiliki. Dengan terjaminnya kedua hal tersebut maka akan diharapkan akan meningkatkan indeks pembangunan manusia yang dimiliki dan nantinya berkontribusi pada pertumbuhan ekonomi.

Penelitian ini menggunakan analisis jalur dimana dihitung pengaruh secara langsung baik secara sendiri-sendiri maupun secara bersama-sama pengaruh anggaran pendidikan dan anggaran kesehatan terhadap indeks pembangunan manusia, selain itu juga dihitung pengaruh langsung maupun tidak langsung terhadap pertumbuhan ekonomi kota Bitung dimana didapatkan hasil yang saling berkaitan dan positif antara masing-masing variable yang diteliti.
\end{abstract}

\section{Kata kunci : Anggaran Pendidikan, anggaran Kesehatan,IPM, Pertumbuhan Ekonomi}

\begin{abstract}
The education budget and the health budget is one of the important components for the operation of human development in the region, due to the guarantee of the quality of human resources that exist and their ability to maintain its human resources. With the assurance of this it will be expected to improve its human development index and will contribute to economic growth.

This study using path analysis which is calculated directly influence either individually or collectively influence the education budget and health budgets towards human development index, but it also calculated the effect of directly or indirectly to economic growth of the city of Bitung in which the obtained results are mutually related and positive between each of the variables studied.
\end{abstract}

Keywords: Budget Education, Health budget, HDI, Economic Growth 


\section{PENDAHULUAN}

\section{Latar Belakang}

Indonesia mempunyai sumber daya alam sangat berlimpah, baik sumber daya terbaharukan (renewable resources) seperti perikanan, pertanian dan kehutanan, maupun sumberdaya tak terbaharukan (nonrenewable resources) seperti minyak bumi, gas, mineral dan bahan tambang lainnya. Dengan potensi yang begitu besar, Perlu adanya dukungan dari sumber daya manusia untuk bisa memanfaatkan potensi yang berlimpah. Terlebih Indonesia sebagai salah satu Negara dengan jumlah penduduk terbesar di dunia, dimana jumlah penduduk Indonesia setidaknya 260 Juta jiwa pada dasawarsa ini. Dengan potensi yang begitu besar dari sumber daya alam maupun manusia tentu Indonesia mampu menjadi Negara Maritim yang hebat apabila ditunjang dengan pembangunan manusia yang baik. Tentu pembangunan manusia tidak terjadi begitu saja namun harus ditunjang, salah satunya adalah melalui sector pendidikan, sampai saat ini mutu pendidikan di Indonesia sampai saat ini masih menjadi "pertanyaan besar" bagi kalangan pemerhati pendidikan, mengingat masih rendahnya mutu pendidikan di Indonesia dibandingkan Negara-negara berkembang lainnya, seperti Malaysia dan Singapura. Demikian pula pemerataan pendidikan di daerah baik sekolah nasional maupun swasta masih menunjukan perbedaan yang cukup tajam, antara sekolah yang berada di kota dan sekolah yang berada di pedesaan. Hal ini belum lagi ditambah dengan factor social ekonomi yang masih rendah membuat para orang tua masih kesulitan mendapatkan pendidikan yang layak dan bermutu bagi anaknya. Sehingga menimbulkan kesan bahwa kebijakan pemerintah belum memihak kepada rakyat kecil.

Menurut analisis Sandiyawan Sumardi, pada akhir dasawarsa ini ada tiga tantangan besar yang harus dihadapi dunia pendidikan Indonesia, pertama, sebagai akibat dari krisis ekonomi, dunia pendidikan di Indonesia dituntut untuk mampu mempertahankan hasil-hasil pembangunan yang selama ini telah dicapai. Kedua, dalam menghadapi era pasar global yang sudah didepan mata pendidikan Indonesia diharapkan untuk dapat mempersiapkan sumber daya manusia yang kompeten dan mampu bersaing di era persaingan yang sudah semakin sengit. Ketiga, sejalan dengan adanya otonomi daerah, pendidikan secara nasional dituntut untuk bisa menyesuaikan pendidikan yang lebih demokratis, memperhatikan keberagaman kebutuhan, keadaan daerah, peserta didik, serta mendorong partisipasi masyarakat. Pasca kenaikan bahan bakar minyak (BBM) tahun 2008 lalu bukan sedikit Negara yang ikut terpengaruh akan keadaan ini, Indonesia juga menjadi salah satu yang ikut tergoncang, dunia pendidikan pun tak lepas dari jerat ini, keadaan ini menimbulkan beberapa gebrakan yang disuarakan oleh masyarakat dan sejumlah pemerhati pendidikan, yakni pendidikan kerakyatan, untuk dapat meringankan beban yang harus ditanggung oleh para orang tua dalam membiayai pendidikan, karena krisis yang terjadi mengakibatkan penurunan daya beli masyarakat termasuk daya beli untuk pendidikan. Sejak tahun 2009 dalam rangka memenuhi amanat undang-undang anggaran pendidikan sebesar $20 \%$ dari anggaran pendapatan dan belanja Negara (APBN) telah mulai dijalankan, meski hal ini dirasa terlambat karena seharusnya sudah dimulai lebih awal 3 sampai 4 tahun sebelumnya, namun seperti kata pepatah lebih baik terlambat dari pada tidak sama sekali. Dengan adanya alokasi anggaran yang begitu besar dari pemerintah terhadap dunia pendidikan Indonesia maka diharapkan kualitas pendidikan akan dapat dijaga, serta dapat menjadi salah satu jalan pemerataan pembangunan yang dimulai dengan meratanya pendidikan.

Struktur anggaran pendidikan sendiri dalam APBN adalah alokasi anggaran pada fungsi pendidikan yang dianggarkan melalui kementrian Negara/lembag, alokasi anggaran pendidikan melalui transfer daerah, dan alokasi anggaran pendidikan melalui pengeluaran pembiayaan, termasuk gaji pendidik tetapi tidak termasuk anggaran pendidikan kedinasan, untuk membiayai penyelenggara pendidikan yang menjadi tanggung jawab pemerintah (pasal 1 butir $40 \mathrm{UU}$ no.4 
tahun 2012 tentang perubahan atas UU no.22 tahun 2011 tentang APBN tahun anggaran 2012). Berdasarkan definisi di atas, maka struktur Anggaran Pendidikan dalam APBN terbagi menjadi tiga bagian yaitu :

$\begin{array}{ll}\text { Pertama } & \text { : Anggaran pendidikan melalui belanja pemerintah pusat } \\ \text { Kedua } & \text { : Anggaran pendidikan melalui transfer ke daerah } \\ \text { Ketiga } & \text { : Anggaran pendidikan melalui pengeluaran pembiayaan }\end{array}$

Anggaran pendidikan melalui belanja pemerintah pusat merupakan alokasi anggaran pendidikan yang dianggarkan melalui kementrian Negara/lembaga. Kementrian Negara/lembaga yang mendapat alokasi anggaran pendidikan bukan hanya kementrian pendidikan dan kebudayaan serta kementrian agama tetapi juga kementrian/lembaga lain yang menyelenggarakan fungsi pendidikan. Anggaran pendidikan melalui transfer ke daerah merupakan alokasi anggaran pendidikan yang disalurkan melalui transfer ke daerah dalam rangka pelaksanaan otonomi daerah. Sebagaimana berdasarkan PP 38 tahun 2007 tentang pembagian urusan pemerintahan antara pemerintah pusat, pemerintah provinsi dan pemerintah daerah kabupaten/kota pendidikan merupakan salah satu urusan wajib daerah. Anggaran pendidikan melalui pengeluaran pembiayaan merupakan anggaran pendidikan yang bersumber dari komponen pembiayaan APBN berupa dana pengembangan pendidikan nasional. Dana pengembangan pendidikan nasional terdiri dari dana abadi pendidikan dan dana cadangan pendidikan. Tujuan :

- Menjamin keberlangsungan pendidikan bagi generasi berikutnya, sebagai bentuk pertanggungjawaban antar generasi (intergenerational equity) yang pengelolaannya menggunakan mekanisme dana bergulir.

- Dana cadangan pendidikan digunakan untuk mengantisipasi keperluan rehabilitasi fasilitas pendidikan yang rusak akibat bencana alam dan dilakukan oleh badan layanan umum (BLU) pengelola dana bidang pendidikan. Dana pengembangan pendidikan nasional ini baru dialokasikan pada tahun anggaran 2010.

Selain dana pendidikan yang mendapatkan alokasi anggaran sebesar $20 \%$, namun juga bidang kesehatan mendapatkan alokasi anggaran yang sama dalam APBN. Sesuai dengan Undang-Undang nomor 25 tahun 2004, tentang Sistem Perencanaan Pembangunan Nasional (SPPN) mengamanatkan bahwa setiap kementrian perlu menyusun Rencana Strategis (Renstra) yang mengacu pada Rencana Pembangunan Jangka Menengah Nasional (RPJMN). Dengan adanya RPJMN 2015-2019 maka pembangunan kesehatan Indonesia adalah program Indonesia sehatdengan sasaran meningkatkan derajat kesehatan dan status gizi masyarakat melalui upaya kesehatan dan pemberdayaan masyarakat yang didukung dengan perlindungan finansial dan pemerataan pelayanan kesehatan. Dengan 6 sasaran pokok, (1)Meningkatkan status kesehatan dan gizi ibu dan anak, (2) meningkatkan pengendalian penyakit, (3) meningkatkan akses dan mutu pelayanan kesehatan dasar dan rujukan terutama di daerah terpencil, tertinggal dan perbatasan, (4) meningkatnya cakupan pelayanan kesehatan universal melalui Kartu Indonesia Sehat dan kualitas pengelolaan SJSN Kesehatan, (5) terpenuhinyua kebutuhan tenaga kesehatan, obat dan vaksin, (6) meningkatnya responsivitas system kesehatan. Dengan adanya alokasi anggaran yang sudah tertata dalam APBN dan merupakan urusan wajib di daerah, maka pemerintah daerah sebagai pelaksana perlu untuk menjalankan fungsi control yang baik dan mengidentifikasi apa saja kebutuhan yang penting dan signifikan di daerah, untuk dapat melakukan pengalokasian anggaran yang tepat sasaran, sehingga dapat menunjukan perkembangan pada indeks pembangunan manusia, serta efek dari pembangunan manusia yang baik dan alokasi anggaran yang cukup besar terhadap pertumbuhan ekonomi di daerah. 
Tabel 1 Perkembangan Pertumbuhan Ekonomi Kota Bitung Tahun 2005-2014

\begin{tabular}{|l|l|l|}
\hline TAHUN & $\begin{array}{l}\text { PERTUMBUHAN } \\
\text { EKONOMI }(\%)\end{array}$ & KETERANGAN \\
\hline 2005 & 7,2 & Tahun dasar 2000 \\
\hline 2006 & 2,91 & Tahun dasar 2000 \\
\hline 2007 & 4,70 & Tahun dasar 2000 \\
\hline 2008 & 6,03 & Tahun dasar 2000 \\
\hline 2009 & 6,05 & Tahun dasar 2000 \\
\hline 2010 & 6,88 & Tahun dasar 2000 \\
\hline 2011 & 7,76 & Tahun dasar 2000 \\
\hline 2012 & 7,98 & Tahun dasar 2000 \\
\hline 2013 & 7,92 & Tahun dasar 2000 \\
\hline 2014 & 6,48 & Tahun dasar 2010 \\
\hline
\end{tabular}

Sumber : Bappeda Kota Bitung

Dalam Tabel 1.1 dapat dilhat bahwa pertumbuhan ekonomi kota Bitung cukup berflutuatif dari tahun ke tahun dengan angka pertumbuhan terendah terjadi pada tahun 2006 dengan hanya 2,91 $\%$ tingkat pertumbuhan ekonomi yang terjadi, dan tertinggi terjadi pada tahun 2012 dengan angka pertumbuhan sebesar 7,98 \%. Dapat dilihat pula bahwa angka rata pertumbuhan berada pada angka $6 \%$, hal ini menjadi gambaran bahwa pertumbuhan ekonomi kota Bitung perlahan-lahan mulai menunjukan perkembangan yang menjanjikan dari tahun ke tahun, namun demikian pertumbuhan ekonomi ini terjadi berdasarkan total keseluruhan Gross Domestik Produk (GDP) yang ada di kota Bitung, tentunya GDP yang ada ini bias terwujud karena sumbangan total pendapatan dari masyarakat secara keseluruhan, dengan adanya alokasi anggaran kesehatan dan pendidikan yang disediakan pemerintah maka diharapkan kemampuan masyarakat untuk ikut berpartisipasi dalam perekonomian juga akan meningkat, dikarenakan pendidikan yang memadai dan kesehatan yang terjaga untuk dapat meningkatkan ekonomi yang ada.

\section{Rumusan Masalah}

Dengan memperhatikan latar belakang yang telah diungkapan maka permasalahan yang akan dianalisis dalam penelitian ini adalah:

1. pengaruh alokasi anggaran kesehatan dan pendidikan terhadap indeks pembangunan manusia

2. pengaruh Indeks pembangunan manusia terhadap pertumbuhan ekonomi

3. pengaruh alokasi anggaran kesehatan dan anggaran pendidikan dan indeks pembangunan manusia terhadap Pertumbuhan Ekonomi

\section{Tujuan Penelitian}

Adapun tujuan penelitian ini untuk mengetahui beberapa pengaruh:

1. alokasi anggaran pendidikan terhadap indeks pembangunan manusia di Kota Bitung?

2. anggaran kesehatan terhadap indeks pembangunan manusia di kota Bitung? 
3. Indeks pembangunan Manusia memberi pengaruh terhadap pertumbuhan ekonomi?

4. alokasi anggaran pendidikan dan kesehatan serta indeks pembangunan manusia mempengaruhi pertumbuhan ekonomi?

\section{Manfaat Penelitian}

Penelitian ini diharapkan dapat memberikan manfaat sebagai berikut:

1. Hasil penelitian ini diharapkan dapat menjadi bahan masukan bagi pelaksana kebijakan untuk dapat melihat penggunaan alokasi anggaran kesehatan dan pendidikan.

2. Hasil penelitian ini diharapkan dapat menjadi masukan terhadap pemerintah dan pihak lain, dalam upaya mencari pendekatan dan strategi terbaik dalam melakukan upaya melaksanakan penganggaran yang baik untuk bidang pendidikan dan kesehatan di daerah.

3. Bagi penulis untuk menambah wawasan terutama yang berhubungan dengan bidang kesehatan, pendidikan, indeks pembangunan manusia dan pertumbuhan ekonomi

4. Sebagai bahan referensi bagi peneliti selanjutnya.

\section{Jenis Penelitian}

\section{METODE PENELITIAN}

Jenis penelitian ini adalah mengetahui pengaruh yang ditimbulkan antara variabel Alokasi anggaran pendidikan dan Alokasi anggaran kesehatan terhadap Indeks pembangunan manusia dan dampaknya terhadap pertumbuhan ekonomi.

\section{Tempat dan Waktu Penelitian}

Tempat penelitian ini adalah di kota Bitung dengan pengambilan data melalui Badan Pusat Statistik (BPS) Provinsi Sulawesi Utara untuk pengambilan data penelitian. Waktu penelitian adalah dari Tahun 2006-2015

\section{Metode Analisis}

Metode analisis yang akan digunakan dalam penelitian ini adalah Analisis Path. Yaitu untuk mengetehui Pengaruh Variabel Independen Exogenus terhadap Variabel Dependen Endogenus yang diformulasikan yang ditunjukkan pada persamaan (dibawah).

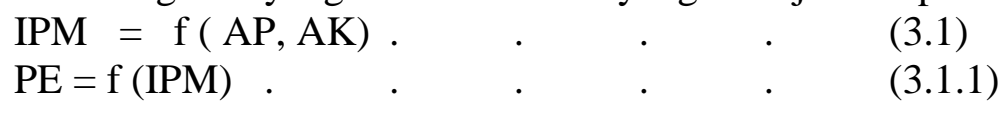

dimana,

$\mathrm{PE} \quad=$ Pertumbuhan Ekonomi

$\mathrm{AP}=$ Anggaran Pendidikan

AK = Anggaran Kesehatan

$\mathrm{IPM}=$ Indeks Pembangunan Manusia

Dari model fungsional persamaan (3.1) dan (3.1.1) dapat ditulis secara model ekonometrika sebagai berikut : 


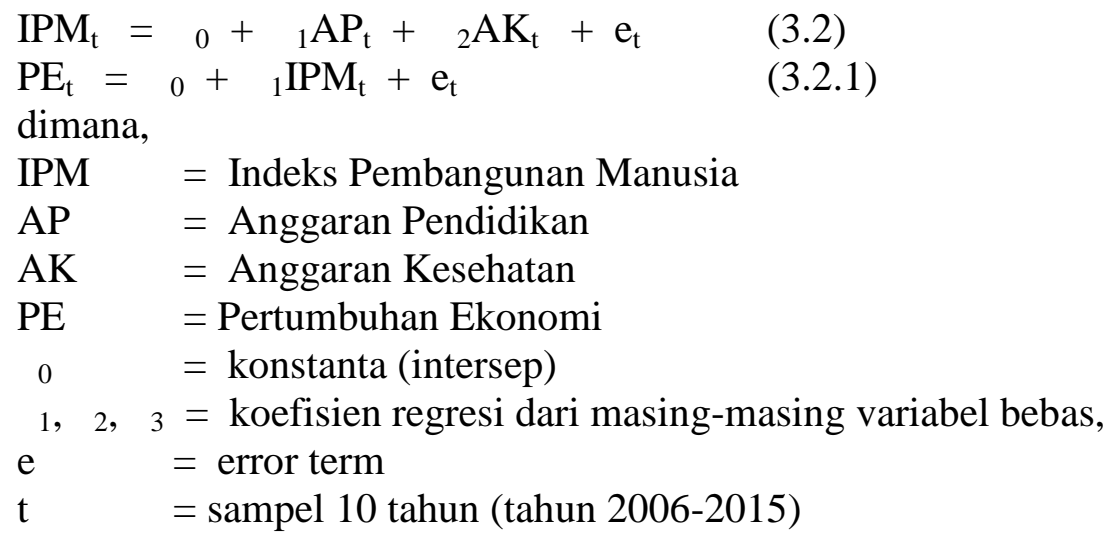

Persamaan (3.2) dan (3.2.2) ditransformasikan kedalam bentuk log-natural seperti yang ditunjukkan persamaan (3.3) dan (3.3.1). Pentransformasian ke dalam bentuk lognatural bertujuan untuk menjadikan nilai variabel-variabel yang dianalisis menjadi seimbang dan juga sekaligus hasil output regresi menunjukkan koefisien slope merupakan tingkat perubahan variabel tidak bebas (dalam persen) bila terjadi perubahan variabelvariabel bebas (dalam persen) Nachrowi, (2006).

$\mathrm{LIPM}_{\mathrm{t}}=\beta_{0}+\beta_{1} \mathrm{LAP}_{\mathrm{t}}+\beta_{2} \mathrm{LAK}_{\mathrm{t}}+\mathrm{e}_{\mathrm{t}}$

$\mathrm{LPE}_{\mathrm{t}}=\beta_{0}+\beta_{1} \mathrm{IPM}_{\mathrm{t}}+\mathrm{e}_{\mathrm{t}}$

dimana,

LIPM = Laju Indeks Pembangunan Manusia

LAP $\quad=$ Pertumbuhan Anggaran Pendidikan

LAK = Pertumbuhan Anggaran Kesehatan

LPE = Laju Pertumbuhan Ekonomi

$\beta_{0} \quad=$ konstanta (intersep)

$\beta_{1}, \beta_{2}, \beta_{3}=$ koefisien regresi dari masing-masing variabel bebas,

$\mathrm{e} \quad=$ error term

$\mathrm{t} \quad=$ sampel 10 tahun (tahun 2006-2015)

\section{Model Jalur}

Model jalur ialah suatu diagram yang menghubungkan jaringan hubungan beberapa variabel yang diletakan secara berurutan yang akan dikaji dalam riset. istilah konvensionalnya ialah hubungan antara variable bebas, perantara dan tergantung. Pola hubungan dalam path analysis ditunjukan dengan menggunakan anak panah. Anak panahanak panah tunggal menujukan hubungan sebab-akibat antara variabel-variabel bebas X1 dan X2 yang dalam path analysis kemudian disebut dengan variabel Exogenus dan/ atau perantara X3 dengan satu variabel tergantung atau lebih yang dalam path analysis disebut sebagai variabel Endogenus Y.

\section{Pengertian dan Tujuan Menggunakan Path Analysis}

"Path analysis merupakan perluasan dari regresi linier berganda, dan yang memungkinkan analisis model-model yang lebih kompleks" (Streiner, 2005). "path analysis 
ialah suatu teknik untuk menganalisis hubungan sebab akibat yang terjadi pada regresi berganda jika varia bel bebasnya mempengaruhi variabel tergsntung tidak hanya secara langsung" (Robert D. Retherford 1993) Sedangkan menurut Paul Webley (1997) "path analysis merupakan pengembangan langsung bentuk regresi berganda dengan tujuan untuk memberikam estimasi tingkat kepentingan ( magnitude) dan signifikasi (significance) hhubungan sebab akibat hipotetikal dalam seperangkat variabel". David Garson (2003) dari North California State University mengidentifikasikan model analysis path sebagai " perluasan regresi yang digunakan untuk menguji keselarasan matriks kolerasi dengan dua atau lebih model hubungan sebab akibat yang dibandingkan oleh peneliti". Modelnya digambarkan dalam bentuk lingkaran dan panah dimana anak panah yang tunggal menunjukan sebagai penyebab. Regresi dikenakan pada masing-masing variabel dalam suatu model sebagai penyebab. Pembobotan regresi diprediksikan dalm suatu model yang dibandingkan dengan matriks kolerasi yang diobservasi untuk semua variabel dan dilakukan juga perhitungan uji keselarasan statistik. Menurut penulis path analysis merupakan teknik analisis yang digunakan untuk menganalisis hubungan sebab akibat yang inheren antara variabel yang disusun berdasarkan urutan temporer dengan menggunakan koefisien jalur sebagai besaran nilai dalam menentukan besarnya pengaruh variabel independen exogenous terhadap variabel dipenden endogenous( Jonathan Sarwono, 2011). Dari definisi diatas dapat sismpulkann bahwa sebenarnya path analysis dapat dikatakan sebagai kepanjangan dari analisis regresi berganda, meski didasarkan sejarah terdapat perbedaan dasar antara path analysis yang bersifat independen terhadap prosedur statistic dalam menentukan hubungan sebab akibat sedang regresi linier memang merupakan prosedur stastik yang digunakan untuk menganalisis hubungan sebab akibat antara variabel yang dikaji.

\section{Tujuan Path Analysis}

Tujuan menggunajkan path analysis diantaranya ialah untuk:

1. Melihat hubangan antara variabel dengan didasarkan pada model apriori

2. Meerangkan mengapa variabel-variabel berkolerasi dengan menggunakan suatu model yang berurutan secara temporer.

3. Menggambar dan menguji suatu model matematis dengan menggunakan persamaan yang mendasarinya.

4. Mengidentifikasi jalur penyebab suatu variabel tertentu terhadap vaariabelvariabel lain yang dipengaruhinya.

5. Menghitung besarnya pengaruh satu variabel independen exogenous atau lebih terhadap variabel dependen endogenous lainya. 


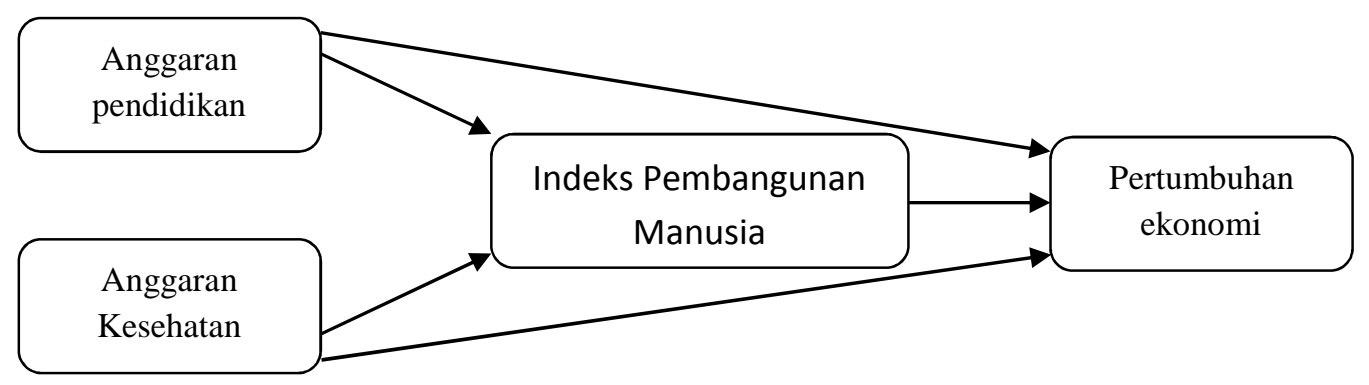

Gambar 1 Diagram Jalur Pengaruh Anggaran Pendidikan dan Anggaran Kesehatan terhadap Indeks Pembangunan Manusia dan dampaknya Terhadap Pertumbuhan Ekonomi

\section{HASIL DAN PEMBAHASAN}

\section{Hasil Penelitian}

Dari hasil penelitian yang di dapat dalam Pengaruh alokasi dana pendidikan dan kesehatan Terhadap indeks pembangunan manusia dan Dampaknya Terhadap pertumbuhan ekonomi adalah sebagai berikut :

\section{Variabel penelitian}

$\mathrm{X}_{1}$ = Belanja Pendidikan

$\mathrm{X}_{2}=$ Belanja Kesehatan

$\mathrm{X}_{3}=$ Indeks Pembangunan Manusia

$\mathrm{Y}=$ Pertumbuhan Ekonomi

\section{Diagram Jalur penelitian}

Dimana dibawah ini merupakan Diagram penelitian yang di lakukan oleh peneliti dalam mencari Pengaruh yang ditimbulkan oleh Variabel Dependen Exogenus terhadap Variabel Independen Exogenus.

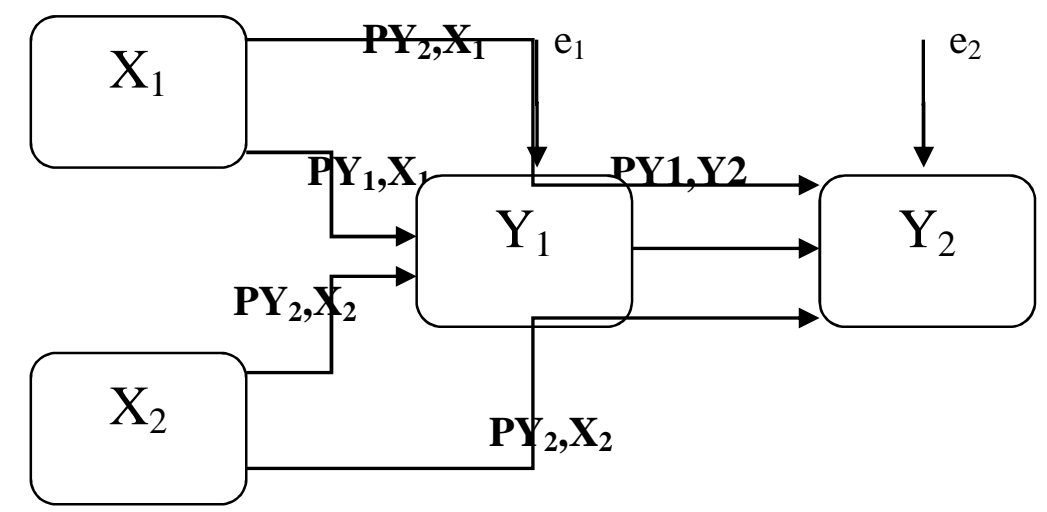

Gambar 2 Diagram Jalur Pengaruh belanja pendidikan dan kesehatan terhadap indeks pembangunan manusia Dan dampaknya terhadap pertumbuhan ekonomi. 
Diagram jalur di atas menunjukan dimana

$\mathrm{X}_{1}$ sebagai Variabel Independen Exogenus Belanja Pendidikan

$\mathrm{X}_{2}$ sebagai Variabel Independen Exogenus Belanja Kesehatan

$\mathrm{Y}_{1}$ sebagai Variabel Dependen Endogenus Indeks Pembangunan Manusia

$\mathrm{Y}_{2}$ sebagai Variabel Endogenus Pertumbuhan Ekonomi

Diagram jalur diatas mempunyai dau persamaan struktural. Persamaan strukturalnya dapat dilihat seperti dibawah ini

$$
\begin{aligned}
& \mathrm{Y}_{1}=\mathrm{PY} 1, \mathrm{X} 1+\mathrm{PY} 1, \mathrm{X} 2+\mathrm{e}_{1} \\
& \mathrm{Y}_{2}=\mathrm{PY}_{2}, \mathrm{X}_{1}+\mathrm{PY}_{2}, \mathrm{X}_{2}+\mathrm{PY}_{2}, \mathrm{Y}_{1}+\mathrm{e}_{2}
\end{aligned}
$$

\section{Perhitungan Sub Struktur I}

\section{Uji R-Square}

Dalam melihat pengaruh Variabel Independen Exogenus anggaran pendidikan dan kesehatan secara gabungan terhadap variabel Dependen Endogenus indeks pembangunan manusia dapat dilihat dari Tabel 4.4 Model Summary dibawah ini.

Tabel 2 R-square

\begin{tabular}{|l|l|l|l|l|l|l|l|}
\hline Model & $\mathrm{R}$ & R Square & $\begin{array}{l}\text { Adjusted R } \\
\text { Square }\end{array}$ & $\begin{array}{l}\text { Std. Error of } \\
\text { the Estimate }\end{array}$ & $\begin{array}{l}\text { Change Statistics } \\
\begin{array}{l}\text { R Square } \\
\text { Change }\end{array}\end{array}$ & F Change & df1 \\
\hline 1 & $.949^{\mathrm{a}}$ & .901 & .877 & .00351 & .901 & 36.506 & 2 \\
\hline
\end{tabular}

a. Predictors: (Constant), ak, ap

b. Dependent Variable: ipm

Sumber Data : pengolahan data 2017

pada nilai $R$ square. Besarnya $R$ square $\left(R^{2}\right)$ pada tabel dibawah ini adalah 0,901 . Angka tersebut mempumpunyai makna Besarnya pengaruh Variabel indeependen exogenous anggaran pendidikan dan kesehatan terhadap variabel dependen endogenus indeks pembangunan manusia secara gabungan. Dalam menghitung Koefisien Determinasi (KD) dapat diketahui dengan rumus

$$
\begin{aligned}
& \mathrm{KD}=\mathrm{R} 2 \times 100 \% \\
& \mathrm{KD}=0,901 \times 100 \% \\
& \mathrm{KD}=90,1 \%
\end{aligned}
$$

Besarnya pengaruh Variabel Independen Exogenous anggaran pendidikan dan kesehatan terhadap Variabel Dependen Endogenus indeks pembangunan manusia secara gabungan adalah 90,1\%. Dan pengaruh di luar model dapat di hitung dengan rumus :

$$
\begin{aligned}
& \mathrm{e}=1-\mathrm{R}^{2} \\
& \mathrm{e}=1-0,901 \\
& \mathrm{e}=0,99 \times 100 \% \\
& \mathrm{e}=9,9 \%
\end{aligned}
$$

Yang berarti 9,9\% adalah besarnya faktor lain yang mempengaruhi diluar model yang di teliti. Artinya besarnya pengaruh variabel independen eksogenus anggaran pendidikan dan kesehatan terhadap variabel dependen endogenus indeks pembangunan 
manusia adalah sebesar 90,1 \%, sedangkan pengaruh sebesar 9,9\% disebabkan oleh variabel di luar model yang di teliti.

Pengaruh variabel independen exogenous anggaran pendidikan dan kesehatan secara parsial terhadap variabel dependen endogenus indeks pembangunan manusia.

Besarnya pengaruh variabel independen exogenous anggaran pendidikan dan kesehatan terhadap variabel dependen endogenus Indeks Pembangunan Manusia secara Parsial dapat dilihat dari nilai Beta atau Standardized Coefficients .dan untuk pengujian digunakan nilai t. Dapat dilihat pada Tabel 3 dibawah ini.

Tabel 3 Coefficients(a)

\begin{tabular}{|c|c|c|c|c|c|}
\hline \multirow[t]{2}{*}{ Model } & \multicolumn{2}{|c|}{$\begin{array}{l}\text { Unstandardized } \\
\text { Coefficients }\end{array}$} & $\begin{array}{l}\text { Standardized } \\
\text { Coefficients }\end{array}$ & \multirow[t]{2}{*}{ t } & \multirow[t]{2}{*}{ Sig. } \\
\hline & $B$ & Std. Error & Beta & & \\
\hline (Constant) & 3.927 & .263 & & 14.948 & .000 \\
\hline ap & .068 & .009 & .922 & 7.593 & .000 \\
\hline ak & .014 & .027 & .064 & .525 & .614 \\
\hline
\end{tabular}

a. Dependent Variable: IPM

Sumber Data : pengolahan data 2017

Pengaruh Variabel Independen Exogenous Anggaran Pendidikan terhadap Variabel Dependen Endogenus Indeks Pembangunan Manusia.

Untuk melihat apakah ada Pengaruh Linier Variabel Independen Exogenus Angaran Pendidikan terhadap Variabel Dependen Endogenus Indeks Pembangunan Manusia. Dapat dilihat pada tabel 3 Coefficients(a) Dengan Analisis :

Hipotesis :

H0 : Tidak ada pengaruh linier antara Variabel Independen Exogenus Anggaran Pendidikan terhadap Variabel Dependen Endogenus Indeks Pembangunan Manusia.

H1 : Ada Pengaruh linier antara Variabel Independen Exogenus Angaran Pendidikan terhadap Variabel Dependen Endogenus Indeks Pembangunan Manusia

Menentukan besarnya taraf Signifikan sebesar 0,05 dan Degree of Freedom DF $=\mathrm{n}$ $-(\mathrm{K}+1)$ atau $\mathrm{DF}=11-(2+1)=9$. Dari ketentuan tersebut diperoleh $\mathrm{t}$ tabel sebesar 3,249 (untuk uji dua arah). Dalam perhitungan SPSS yang tertera pada tabel Coefficients di atas dimana tabel $\mathrm{t}$ adalah untuk menunjukan bahwa adanya Pengaruh linier antara Variabel Independen Exogenus Anggaran Pendidikan terhadap Variabel Dependen Endogenus Indeks Pembangunan Manusia ialah 7,593.

Pengujian Hipotesis t kriterianya sebagai berikut :

Jika t hitung > t tabel, maka $\mathrm{H} 0$ ditolak, dan $\mathrm{H} 1$ diterima

Jika t hitung < t tabel, maka H0 diterima, dan H1 ditolak

Dimana dalam melihat pengaruh signifikan atau tidak Kriterianya adalah sebagai berikut :

Jika Signifikan $<0,05$ maka berpengaruh signifikan

Jika Signifikan > 0,05 maka tidak ada pengaruh signifikan 
Hasil dari perhitungan dengan SPSS menunjukan angka t hitung sebesar 7,593 > t tabel sebesar 3,249. Dengan demikian keputusanya ialah H0 ditolak, dan H1 diterima. Artinya ada hubungan linier antara Variabel Independen Exogenus anggaran pendidikan terhadap Variabel Dependen Endogenus Indeks Pembangunan Manusia. Maka Variabel Independen Exogenus Anggaran Pendidikan berpengaruh terhadap Variabel Dependen Endogenus indeks Pembangunan Manusia. Besarnya Koefisien Beta pada tabel 3 di atas (dalam kolom Standardized Coefficient Beta) sebesar 0,922 atau jika dibuat persen menjadi sebesar 92,2\% menunjukan bahwa pengaruh sebesar ini signifikan karena nilai signifikansi / probabilitas hasil yang tertera pada kolom Sig $0,00<0,05$.

\section{Pengaruh antara variabel Independen Exogenus Anggaran Kesehatan terhadap Variabel Dependen Endogenus Indeks Pembangunan Manusia}

Untuk melihat apakah ada Pengaruh Linier Variabel Independen Exogenus Angaran kesehatan terhadap Variabel Dependen Endogenus Indeks Pembangunan Manusia. Dapat dilihat pada tabel 3 Coefficients(a) Dengan Analisis :

Hipotesis :

H0 : Tidak ada pengaruh linier antara Variabel Independen Exogenus Anggaran Kesehatan terhadap Variabel Dependen Endogenus Indeks Pembangunan Manusia.

H1 : Ada Pengaruh linier antara Variabel Independen Exogenus Angaran Kesehatan terhadap Variabel Dependen Endogenus Indeks Pembangunan Manusia

Menentukan besarnya taraf Signifikan sebesar 0,05 dan Degree of Freedom $\mathrm{DF}=\mathrm{n}$ $-(\mathrm{K}+1)$ atau $\mathrm{DF}=11-(2+1)=9$. Dari ketentuan tersebut diperoleh t tabel sebesar 3,249 (untuk uji dua arah). Dalam perhitungan SPSS yang tertera pada tabel Coefficients di atas dimana tabel $\mathrm{t}$ adalah untuk menunjukan bahwa adanya Pengaruh linier antara Variabel Independen Exogenus Anggaran Pendidikan terhadap Variabel Dependen Endogenus Indeks Pembangunan Manusia ialah 0,525. Pengujian Hipotesis t kriterianya sebagai berikut :

Jika t hitung > t tabel, maka $\mathrm{H} 0$ ditolak, dan $\mathrm{H} 1$ diterima

Jika t hitung < t tabel, maka H0 diterima, dan H1 ditolak

Dimana dalam melihat pengaruh signifikan atau tidak Kriterianya adalah sebagai berikut :

Jika Signifikan $<0,05$ maka berpengaruh signifikan

Jika Signifikan > 0,05 maka tidak ada pengaruh signifikan

Hasil dari perhitungan dengan SPSS menunjukan angka t hitung sebesar 0,525<t tabel sebesar 3,249. Dengan demikian keputusanya ialah H0 diterima, dan H1 ditolak. Artinya tidak ada hubungan linier antara Variabel Independen Exogenus anggaran Kesehatan terhadap Variabel Dependen Endogenus Indeks Pembangunan Manusia. Maka Variabel Independen Exogenus Anggaran Kesehatan tidak berpengaruh terhadap Variabel Dependen Endogenus indeks Pembangunan Manusia. Besarnya Koefisien Beta pada tabel 3 di atas (dalam kolom Standardized Coefficient Beta) sebesar 0,064 atau jika dibuat persen menjadi sebesar 6,4 \% menunjukan bahwa pengaruh sebesar ini tidak signifikan karena nilai signifikansi / probabilitas hasil yang tertera pada kolom Sig 0,61 > 0,05.

\section{Melihat Kelayakan Model Regresi}

untuk mengetahui model regresi yang telah dibuat sudah benar adalah dengan menggunakan pengujian dengan menggunakan pengujian dengan dua cara, yaitu Pertama 
menggunakan nilai $\mathrm{F}$ pada tabel keluaran ANOVA, dan Kedua dengan cara menggunakan nilai Probabilitas / nilai Sig pada tabel keluaran ANOVA.

Tabel 4 ANOVA(b)

\begin{tabular}{|ll|l|l|l|l|l|}
\hline Model & $\begin{array}{l}\text { Sum of } \\
\text { Squares }\end{array}$ & df & Mean Square & F & Sig. \\
\hline 1 & Regression & .001 & 2 & .000 & 36.506 & $.000^{\mathrm{b}}$ \\
\hline & $\begin{array}{l}\text { Residual } \\
\text { Total }\end{array}$ & .000 & 8 & .000 & & \\
\hline
\end{tabular}

a. Dependent Variable: ipm

b. Predictors: (Constant), ak, ap

Sumber Data : pengolahan data 2017

Uji Hipotesis Menggunakan Angka F. Hipotesis :

$\mathrm{H} 0$ : Tidak ada pengaruh linier antara Variabel Independen Exogenus anggaran pendidikan dan kesehatan terhadap Variabel Dependen Endogenus indeks pembangunan Manusia.

H1 : Ada pengaruh linier antara Variabel Independen Exogenus anggaran pendidikan dan kesehatan terhadap Variabel Dependen Endogenus indeks pembangunan manusia.

Menghitung nilai $\mathrm{F}$ tabel dengan Ketentuan besar nilai taraf Signifikansi sebesar 0,05 dan Nilai Degree Of Freedom dengan ketentuan Numerator / Vektor 1 : Jumlah Variabel - 1 atau $3-1=2$, dan dumerator / Vektor 2 : jumlah kasus-jumlah variabel atau $11-3=8$. Dengan ketentuan terdebut diperoleh angka $F$ tabel sebesar 4,460.

Dengan kriteria pengambilan keputusan hasil pengujian hipotesis

Jika F hitung > F tabel, maka H0 ditolak, H1 diterima.

Jika F hitung < F tabel, maka H0 diterima dan H1 ditolak.

Hasil uji hipotesis adalah :

Hasil perhitungan dengan SPSS didapatkan angka $\mathrm{F}$ hitung sebesar 36,506 > F tabel sebesar 6,314. Dengan demikian H0 ditolak, dan H1 diterima. Artinya ada hubungan linier antara Variabel Independen Eksogenus anggaran pendidikan dan kesehatan dengan Variabel Dependen Endogenus indeks pembangunan manusia. Dengan nilai Sig 0,013 Kesimpulan adalah model regresi di atas sudah layak dan benar.

\section{Perhitungan Sub Struktur II}

Pengaruh Variabel Independen Eksogenus Anggaran pendidikan dan Anggaran Kesehatan serta Indeks Pembangunan Manusia Secara Gabungan Terhadap Variabel Dependen Endogenus Pertumbuhan Ekonomi.

Untuk melihat hubungan pengaruh variabel Independen Exogenus anggaran pendidikan, anggaran kesehatan dan indeks pembangunan manusia terhadap Pertumbuhan Ekonomi secara gabungan dapat dilihat pada Tabel Model Summary, dalam angka R square di bawah ini. 
Tabel 5 Model Summary(b)

\begin{tabular}{|c|c|c|c|c|c|c|c|}
\hline \multirow{2}{*}{ Model } & \multirow[t]{2}{*}{$\bar{R}$} & \multirow[t]{2}{*}{ R Square } & \multirow{2}{*}{$\begin{array}{l}\text { Adjusted R } \\
\text { Square }\end{array}$} & \multirow{2}{*}{$\begin{array}{l}\text { Std. Error of } \\
\text { the Estimate }\end{array}$} & \multicolumn{3}{|c|}{ Change Statistics } \\
\hline & & & & & $\begin{array}{l}\text { R Square } \\
\text { Change }\end{array}$ & F Change & df1 \\
\hline$\sqrt{1}$ & $\overline{615^{\mathrm{a}}}$ & .378 & .112 & .12051 & .378 & $\overline{1.419}$ & $\sqrt{3}$ \\
\hline
\end{tabular}

a Predictors: (Constant), AP,AK,IPM

b Dependent Variable: PE

Sumber Data : pengolahan data 2017

besarnya pengaruh Rsquare $\left(\mathrm{R}^{2}\right)$ pada tabel diatas adalah 0378 . Angka tersebut mempunyai makna besarnya pengaruh variabel independen anggaran pendidikan, anggaran kesehatan, dan indeks pembangunan manusia terhadap Pertumbuhan Ekonomi secara gabungan. dalam menghitung Koefisien Determinasi (KD) dapat di hitung dengan Rumus sebagai berikut.

$$
\begin{aligned}
& \mathrm{KD}=\mathrm{R} 2 \times 100 \% \\
& \mathrm{KD}=0,37,8 \times 100 \% \\
& \mathrm{KD}=37,8 \%
\end{aligned}
$$

Angka 37,8 \% mempunyai makna besarnya pengaruh Variabel Independen anggaran pendidikan, anggaran kesehatan, dan indeks pembangunan manusia terhadap Pertumbuhan Ekonomi secara gabungan. sedangkan sisanya dapat dihitung dengan menggunakan rumus sebagai berikut :

$$
\begin{aligned}
& \mathbf{e}=1-\mathrm{R} 2 \\
& \mathbf{e}=1-0,378 \\
& \mathbf{e}=0,622 \\
& \mathbf{e}=0,622 \times 100 \% \\
& \mathbf{e}=62,2 \%
\end{aligned}
$$

Variabelitas Pertumbuhan Ekonomi yang dapat diterangkan dengan menggunakan Variabel Independen Exogenus anggaran pendidikan, anggaran kesehatan, dan indeks pembangunan manusia adalah sebesar $37,8 \%$, sedangkan besarnya pengaruh dari Variabel diluar model adalah sebesar 62,2\%.

Pengaruh Variabel Independen Exogenus Anggaran Pendidikan, Anggaran Kesehatan dan Indeks Pembangunan Manusia Secara Parsial terhadap Variabel Dependen Endogenus Pertumbuhan Ekonomi.

Besarnya pengaruh Variabel Independen Exogenus anggaran pendidikan, anggaran kesehatan, dan indeks pembangunan manusia terhadap Pertumbuhan Ekonomi secara Parsial. 
Tabel 6 Coefficients(a)

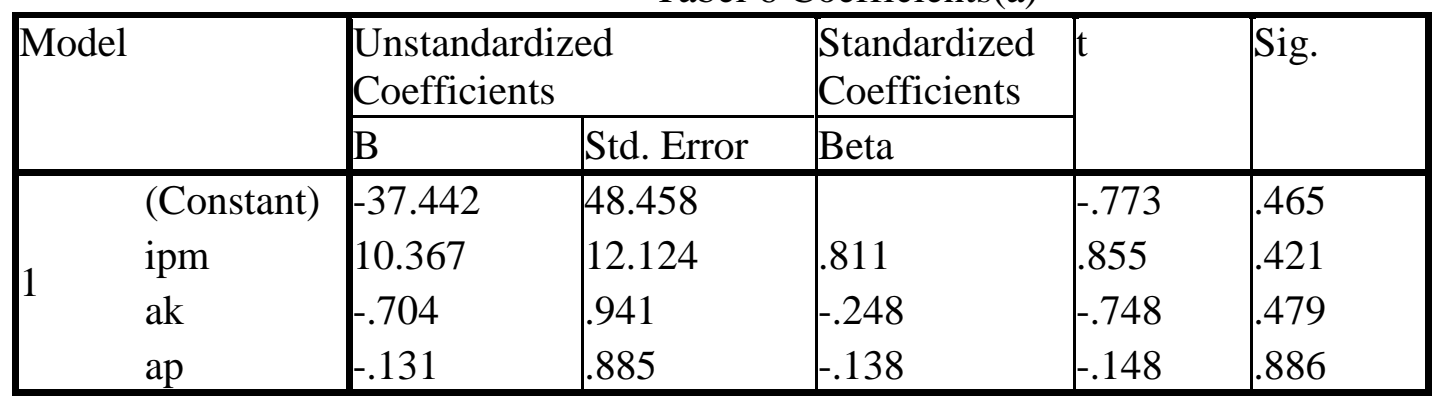

a Dependent Variable: Pertumbuhan Ekonomi

Sumber Data : pengolahan data 2017

\section{Pengaruh antara variabel Independen Exogenus Anggaran Pendidikan dengan Variabel Dependen Endogenus Pertumbuhan Ekonomi.}

Dengan hipotesis :

H0 : Tidak ada pengaruh linier antara variabel Independen Eksogenus anggaran pendidikan terhadap Variabel Dependen Endogenus Pertumbuhan Ekonomi

H1 : Adanya pengaruh linier antara Variabel Independen Exogenus anggaran pendidikan terhadap Variabel Dependen Endogenus Pertumbuhan Ekonomi

Dari hasil perhitungan dengan menggunakan SPSS yang tertera pada kolom t pada tabel Coefficients diatas untuk menunjukan adanya hubungan linier antara Variabel Independen Exogenus Anggaran Pendidikan dengan Variabel Dependen Endogenus Pertumbuhan Ekonomi ialah sebesar -0,148. Menentukan besarnya angka $t$ tabel / nilai kritis dari tabel $t$ dengan ketentuan sebagai berikut :

Menentukan besarnya taraf signifikansi sebesar 0,05 dan Degree of Freedom DF dengan ketentuan : $\mathrm{DF}=\mathrm{n}-(\mathrm{K}+1)$ atau $\mathrm{DF}=11-(3+1)$ dari ketentuan tersebut diperoleh angka $\mathrm{t}$ tabel untuk uji dua sisi adalah sebesar 3,499 Dalam pengujian hipotesis t kriterianya sebagai berikut :

Jika t hitung > t tabel, maka H0 di tolak. Dan H1 diterima

Jika t hitung $<\mathrm{t}$ tabel, maka H0 diterima. Dan H1 ditolak

Untuk menunjukan pengaruh signifikan atau tidak kriterianya sebagai berikut :

Jika Sig < 0,05, maka berpengaruh Signifikan

Jika Sig > 0,05, maka tidak berpengaruh Signifikan

Hasil Pengujian :

Hasil dari perhitungan dengan menggunakan SPSS menunjukan angka t hitung sebesar $0,148<3,499$, dengan demikian keputusanya adalah $\mathrm{H} 0$ diterima, dan $\mathrm{H} 1$ ditolak. Artinya tidak ada hubungan linier antara Variabel Independen Anggaran pendidikan terhadap Variabel Dependen Endogenus Pertumbuhan Ekonomi. Nilai koefisien Beta ( dalam kolom Standardized Coefficient Beta) sebesar 0,138 atau jika dibuat dalam persen menjadi 13,8\% menunjukan bahwa pengaruh sebesar ini tidak signifikan karena nilai signifikansi / probabilitas hasil perhitungan yang tertera dalam kolom sig sebesar $0,886>0,05$. 
Pengaruh antara Variabel Independen Exsogenus Retribusi terhadap Variabel Independen Endogenus Pertumbuhan Ekonomi.

Dengan hipotesis :

H0 : Tidak ada pengaruh linier antara variabel Independen Eksogenus anggaran kesehatan terhadap Variabel Dependen Endogenus Pertumbuhan Ekonomi

H1 : Adanya pengaruh linier antara Variabel Independen Exogenus anggaran kesehatan terhadap Variabel Dependen Endogenus Pertumbuhan Ekonomi

Dari hasil perhitungan dengan menggunakan SPSS yang tertera pada kolom t pada tabel Coefficients diatas untuk menunjukan adanya hubungan linier antara Variabel Independen Exogenus Anggaran Kesehatan dengan Variabel Dependen Endogenus Pertumbuhan Ekonomi ialah sebesar -0,748. Menentukan besarnya angka $t$ tabel / nilai kritis dari tabel $t$ dengan ketentuan sebagai berikut : Menentukan besarnya taraf signifikansi sebesar 0,05 dan Degree of Freedom DF dengan ketentuan : DF $=\mathrm{n}-(\mathrm{K}+1)$ atau $\mathrm{DF}=11-(3+1)$ dari ketentuan tersebut diperoleh angka t tabel untuk uji dua sisi adalah sebesar 3,499, Dalam pengujian hipotesis t kriterianya sebagai berikut :

Jika t hitung > t tabel, maka H0 di tolak. Dan H1 diterima

Jika t hitung < t tabel, maka H0 diterima. Dan H1 ditolak

Untuk menunjukan pengaruh signifikan atau tidak kriterianya sebagai berikut :

Jika Sig < 0,05, maka berpengaruh Signifikan

Jika Sig > 0,05, maka tidak berpengaruh Signifikan

Hasil Pengujian :

Hasil dari perhitungan dengan menggunakan SPSS menunjukan angka t hitung sebesar $0,748<3,499$, dengan demikian keputusanya adalah $\mathrm{H} 0$ diterima, dan $\mathrm{H} 1$ ditolak. Artinya tidak ada hubungan linier antara Variabel Independen Anggaran Kesehatan terhadap Variabel Dependen Endogenus Pertumbuhan Ekonomi. Nilai koefisien Beta ( dalam kolom Standardized Coefficient Beta) sebesar 0,248 atau jika dibuat dalam persen menjadi 24,8\% menunjukan bahwa pengaruh sebesar ini tidak signifikan karena nilai signifikansi / probabilitas hasil perhitungan yang tertera dalam kolom sig sebesar 0,479>0,05.

\section{Pengaruh antara Variabel Independen Exsogenus Indeks Pembangunan Manusia terhadap Variabel Independen Endogenus Pertumbuhan Ekonomi.}

Dengan hipotesis :

H0 : Tidak ada pengaruh linier antara variabel Independen Exogenus indeks pembangunan manusia terhadap Variabel Dependen Endogenus Pertumbuhan Ekonomi

H1 : Adanya pengaruh linier antara Variabel Independen Exogenus indeks pembangunan manusia terhadap Variabel Dependen Endogenus Pertumbuhan Ekonomi

Dari hasil perhitungan dengan menggunakan SPSS yang tertera pada kolom t pada tabel Coefficients diatas untuk menunjukan adanya hubungan linier antara Variabel Independen Exogenus Indeks Pembangunan Manusia dengan Variabel Dependen Endogenus Pertumbuhan Ekonomi ialah sebesar -0,255. Menentukan besarnya angka t tabel / nilai kritis dari tabel $t$ dengan ketentuan sebagai berikut : 
Menentukan besarnya taraf signifikansi sebesar 0,05 dan Degree of Freedom DF dengan ketentuan : $\mathrm{DF}=\mathrm{n}-(\mathrm{K}+1)$ atau $\mathrm{DF}=11-(3+1)$ dari ketentuan tersebut diperoleh angka $\mathrm{t}$ tabel untuk uji dua sisi adalah sebesar 3,499. Dalam pengujian hipotesis t kriterianya sebagai berikut :

Jika t hitung $>\mathrm{t}$ tabel, maka $\mathrm{H} 0$ di tolak. Dan $\mathrm{H} 1$ diterima

Jika t hitung < t tabel, maka H0 diterima. Dan H1 ditolak

Untuk menunjukan pengaruh signifikan atau tidak kriterianya sebagai berikut :

Jika Sig < 0,05, maka berpengaruh Signifikan

Jika Sig > 0,05, maka tidak berpengaruh Signifikan

Hasil Pengujian :

Hasil dari perhitungan dengan menggunakan SPSS menunjukan angka t hitung sebesar $0,255<3,499$, dengan demikian keputusanya adalah H0 diterima, dan H1 ditolak. Artinya tidak ada hubungan linier antara Variabel Independen Indeks Pembangunan Manusia terhadap Variabel Dependen Endogenus Pertumbuhan Ekonomi. Nilai koefisien Beta ( dalam kolom Standardized Coefficient Beta) sebesar 0,811 atau jika dibuat dalam persen menjadi $81,1 \%$ menunjukan bahwa pengaruh sebesar ini tidak signifikan karena nilai signifikansi / probabilitas hasil perhitungan yang tertera dalam kolom sig sebesar 0,421 > 0,05 .

\section{Melihat Kelayakan Model Regresi Struktur II}

Untuk mengetahuimodel Regresi yang dibuat telah benar adalah dengan menggunakan Pengujian dua cara yaitu pertama menggunakan nilai $\mathrm{F}$ pada tabel keluaran ANOVA, dan kedua dengan cara menggunakan nilai Probabilitas nilai Sig pada tabel keluaran ANOVA.

Tabel 7 Anova

\begin{tabular}{|ll|l|l|l|l|l|}
\hline Model & $\begin{array}{l}\text { Sum of } \\
\text { Squares }\end{array}$ & Df & Mean Square & F & Sig. \\
\hline & Regression & .062 & 3 & .021 & 14.419 & $.315^{\mathrm{b}}$ \\
1 & Residual & .102 & 7 & .015 & & \\
\hline & Total & .163 & 10 & & & \\
\hline
\end{tabular}

a. Dependent Variable: Pertumbuhan Ekonomi

b. Predictors: (Constant), AP,AK,IPM

Uji Hipotesis Menggunakan Angka F

Hipotesis :

H0 : Tidak ada pengaruh linier antara variabel Independen Exogenous Anggaran

Pendidikan, Anggaran Kesehatan, Indeks Pembangunan Manusia terhadap variabel Dependen Endogenus Pertumbuhan Ekonomi 
H1 : ada hubungan linier antara variabel Independen Eksogenus Anggaran Pendidikan, Anggaran Kesehatan, Indeks Pembangunan Manusia terhadap variabel Dependen Endogenus Pertumbuhan ekonomi.

Nilai F hitung dari keluaran SPSS ialah 14,419. Menghitung nilai F tabel dengan ketentuan nilai besar nilai taraf signifikasi sebesar 0,05 dan nilai DF / Vektor 1 : jumlah variabel - 1 atau 4-1 = 3 dan dumerator Vektor : jumlah kasus - jumlah variabel atau $11-4=8$ dengan ketentuan tersebut diperoleh angka $\mathrm{F}$ tabel sebesar 3,840. Dengan kriteria pengambilan keputusan hasil pengujian hipotesis

Jika F hitung > F tabel, maka H0 ditolak, H1 dan diterima.

Jika $\mathrm{F}$ hitung $<\mathrm{F}$ tabel, maka $\mathrm{H} 0$ diterima dan $\mathrm{H} 1$ ditolak

Hasil perhitungan dengan SPSS didapat angka F hitung sebesar 14,419 > F tabel sebesar 3,840. Dengan demikian H0 ditolak, dan H1 diterima dengan demikian Ada pengaruh linier antara variabel Independen anggaran pendidikan, anggaran kesehatan, dan indeks pembangunan manusia terhadap variabel Dependen Endogenus Pertumbuhan Ekonomi. Kesimpulan adalah model regresi diatas sudah layak dan benar.

Menghitung Pengaruh Langsung DE (Direct Effect)

Pengaruh Variabel Anggaran Pendidikan terhadap Indeks Pembangunan Manusia

$\mathrm{X} 1 \mathrm{ke} \mathrm{Y} 1=7,593$

Pengaruh Variabel Anggaran Kesehatan terhadap Indeks Pembangunan Manusia

$\mathrm{X} 2$ ke $\mathrm{Y} 1=0,525$

Pengaruh Variabel anggaran pendidikan terhadap Pertumbuhan Ekonomi

$\mathrm{X} 1 \mathrm{ke} \mathrm{Y} 2=-, 148$

Pengaruh Variabel anggaran kesehatan terhadap Pertumbuhan Ekonomi

$\mathrm{X} 2$ ke $\mathrm{Y} 2=-, 748$

Pengaruh Variabel Belanja Langsung terhadap Pertumbuhan Ekonomi

Y1 ke $\mathrm{Y} 2=0,855$

\section{Pengaruh Tidak Langsung IE (Indirect Effect)}

Pengaruh variabel anggaran pendidikan terhadap Pertumbuhan Ekonomi Melalui Indeks Pembangunan Manusia

$$
\text { PY1X1 x PY2Y1 = }(7,593 \times 0,855)=6,719
$$

Pengaruh variable anggaran kesehatan terhadap Pertumbuhan Ekonomi melalui Indeks Pembangunan Manusia

$$
\text { PY1X2 x PY2Y1 }=(0.525 \times 0,855)=0,448
$$

\section{Pengaruh Total (Total Effect)}

Pengaruh anggaran pendidikan dan indeks pembangunan manusia terhadap Pertumbuhan Ekonomi

$$
\text { PY1X1 + PY2Y1 7,593 + } 0,855=8,448
$$

Pengaruh Variabel anggaran kesehatan dan indeks pembangunan manusia tehadap Pertumbuhan Ekonomi.

$$
\mathrm{PY} 1 \mathrm{X} 2+\mathrm{PY} 2 \mathrm{Y} 1=0.525+0,855=1,380
$$




\section{Pembahasan}

Berdasarkan hasil penghitungan yang dilakukan, didapatkan hasil bahwa alokasi anggaran dari pemerintah kota Bitung, baik untuk anggaran pendidikan maupun anggaran kesehatan mempunyai korelasi atau hubungan yang positif dengan pembangunan manusia yang ada di Kota Bitung, bahkan tingkat perubahan yang terjadi pada indeks pembangunan manusia Kota Bitung sebagian besar mampu dijelaskan oleh anggaran pendidikan maupun anggaran kesehatan. Hal ini menjadi gambaran nyata bagaimana pemerintah dalam hal ini dalam upaya untuk terus meningkatkan pembangunan manusia yang dimiliki, yang tentunya dapat dilihat dari kemampuan sumber daya manusia yang semakin baik haruslah berinvestasi pada bidang pendidikan maupun pada bidang kesehatan. Berdasarkan data dan hasil penghitungan yang dilakukan makin besar nilai investasi pemerintah baik melalui anggaran pendidikan maupun anggaran kesehatan yang dimiliki maka akan semakin baik pula indeks pembangunan manusia yang dimiliki oleh Kota Bitung.

Tentunya dengan indeks pembangunan manusia yang semakin baik maka juga akan meningkatkan kemampuan maupun daya saing yang dimiliki oleh sumber daya manusia, baik melalui keahlian, kemampuan maupun ilmu yang diterima saat mengenyam bangku pendidikan serta semakin baiknya kemauan untuk berusaha karena kesehatan yang dijamin dan diperhatikan oleh pemerintah, sehingga pembangunan infrastruktur yang dilakukan juga bisa berjalan beriringan dengan pembangunan manusianya. Tentunya tak hanya berhenti di pembangunan manusia dan mengedepankan kemampuan bersaing yang dimiliki namun juga perlu adanya peningkatan perekonomian yang kelihatan dinilai dari tingkat pertumbuhan ekonomi yang dimiliki kota Bitung. Berdasarkan analogi yang disusun penulis, seharusnya pertumbuhan ekonomi dan indeks pembangunan manusia mempunyai hubungan yang saling menguntungkan atau saling berpengaruh positif satu sama lain, namun dalam penelitian ini dalam jangka pendek atau hanya selama tahun penelitian didapatkan hasil bahwa pembangunan yang dilakukan pemerintah di sisi sumber daya manusia, tidak langsung berkolerasi positif dengan pertumbuhan ekonomi, hal ini masih dianggap cukup wajar, apalagi melihat pertumbuhan ekonomi kota Bitung yang terus mengalami peningkatan atau terus menunjukan angka pertumbuhan yang positif dari tahun ke tahun menunjukan perekonomian di kota Bitung sendiri terus tumbuh setiap tahunnya, hal ini terlepas dari pengalokasian anggaran pemerintah di bidang pendidikan dan kesehatan yang masih amat minim dan berflutuatif setiap tahunnya. Padahal sebagaimana dijelaskan sebelumnnya alokasi anggaran pendidikan amupun kesehatan yang dialokasikan pemerintah mempunyai peranan sangat besar dan signifikan terhadap indeks pembangunan manusia di Kota Bitung, sehingga dapat diambil kesimpulan bahwa dalam jangka pendek pengalokasian anggaran pendidikan dan anggaran kesehatan di kota Bitung hanya memberi pengaruh jangka pendek terhadap indeks pembngunan manusia, sedangkan untuk pengaruhnya pada pertumbuhan ekonomi dalam jangka pendek tidak ada. Memang seharunya alokasi anggaran pendidikan adalah bentuk investasi jangka panjang dalam menumbuhkan daya saing di masa depan.

\section{DAFTAR PUSTAKA}

Abdul Halim. (2003). Analisis Investasi. Edisi Pertama, Penerbit Salemba Empat : Jakarta Abu Ahmadi \& Supriyono Widodo. (2004). Psikologi Belajar. Jakarta: PT Rineka Cipta. 
Ahmadi dan Uhbiyati. 2007. Ilmu Pendidikan. Jakarta: Rineka Cipta

Aji Supriyanto (2005:238), Pengertian Sistem, Ekosiana. Yogyakarta

Agus salim dan Andi Ganjong, 2007, Pemerintahan Daerah Kajian Politik Hukum , Bogor, Ghalia Indonesia

Adi Widodo, Waridin, Johanna Maria K,2011, Analisis Pengaruh Pengeluaran pemerintah di sector pendidikan dan kesehatan terhadap pengentasan kemiskinan melalui peningkatan pembangunan manusia di Provinsi Jawa Tengah

Adi, Priyo H, Fhino Andrea Christy. 2009. Hubungan antara Dana Alokasi Umum, Belanja Modal dan Kualitas Pembangunan Manusia. Surabaya: The 3rd National Conference UKWMS.

Adi Putra, 2013, Analisis Pengaruh Tingkat Pengangguran Terbuka, Pertumbuhan Ekonomi, Pengeluaran Pemerintah Sektor Pendidikan Dan Kesehatan Terhadap Indeks Pembangunan Manusia Di Provinsi Lampung Tahun 1995-2012

Bastian, Indra, Gatot Soepriyanto, 2002. Sistem Akuntansi Sektor Publik Konsep Untuk Pemerintah Daerah, Edisi Pertama, Salemba Empat, Jakarta.

Brata, 2005, Perencanaan Pembangunan Daerah, Gramedia Pustaka Utama, JakartaChemingui (2007)

David, Garson, 2003. Path Analysis. North Carolina State University.

Halim, Abdul, 2004, Akuntansi Keuangan Daerah, Penerbit Salemba Empat, Jakarta

Ilyas, Abdul Hamid Paddu, Sultan Suhab, 2012, Pengaruh Pengeluaran pemerintah sector pendidikan dan sector kesehatan terhadap IPM dan Pertumbuhan Ekonomi Kabupaten Sinjai

Jonathan Sarwono, 2006, Metode Penelitian Kuantitatif \& Kualitatif, (Yogyakarta; Graha Ilmu,

Mahmudi, 2007, Manajemen Kinerja Sektor Publik, Yogyakarta. Unit penerbit dan percetakan Sekolah Tinggi Ilmu Manajemen YKPN

Musgrave, Richard A Musgrave, Peggy B. Public Finance in Theory and Practise. 1989 Mc Graw Hill Book Company.Toyamah, dkk (2004)

Michael Boozer, Gustav Ranis, Frances Stewart, Tavneet Suri, 2003, paths to success: the relationship between human development and economic growth, Yale University.

Mardiasmo. 2002. Akuntansi Sektor Publik. Penerbit Andi. Yogyakarta.

Mulyaningsih, Yani. 2008. Pengaruh pengeluaran pemerintah di sektor public terhadap peningkatan pembangunan manusia dan pengurangan kemiskinan. Tesis : Universitas Indonesia.

Yuhenda, 2013, Pengaruh Kualitas Pendidikan, Kesehatan dan investasi terhadap pertumbuhan ekonomi Sumatera Barat

Sadono Sukirno, 2006, Ekonomi Pembangunan Proses masalah dan Dasar Kebijakan, cetakan ketiga, Penerbit Kencana, Jakarta.

Singgih Santoso, 2002 Mengolah Data Statistik Secara Professional, Elex Media Komputindo, Jakarta.

Tri Maryani, 2010, Analisis Indeks pembangunan manusia di provinsi Jawa Tengah Undang-Undang No.32 Tahun 2004 Tentang Pemerintahan Daerah (Lembaran Negara Republik Indonesia Tahun 2004 Nomor 125) 
Undang-Undang No.33 tahun 2004 Tentang Perimbangan Keuangan Antara Pemerintah Pusat Dan Pemerintah Daerah. ( Lembaran Negara Republik Indonesia Tahun 2004 Nomor 126)

Peraturan Pemerintah No. 58 Tahun 2005 Tentang Pengelolaan Keuangan Daerah

BPS Propinsi Sulawesi Utara 